\title{
PEMODELAN MATEMATIKA DALAM SISTEM MASSA PEGAS
}

\author{
Muh. Irwan ${ }^{\mathrm{i}}$, Erniwati Jalii ${ }^{\mathrm{ii}}$
}

${ }^{i}$ Prodi Matematika FST, UINAM, muirwan@uin-alauddin.ac.id

ii Prodi matematika FMIPA, UMMA, erniwatijalil@gmail.com

\begin{abstract}
ABSTRAK, Pada paper ini diperkenalkan teori pemodelan matematika dalam bidang fisika khususnya pada sistem massa pegas teredam linear dengan massa tidak constant. Hasil yang diperoleh adalah suatu model matematika dalam bentuk pesamaan diferensial linear orde dua dengan koefisien tidak constant. Adapun solusi persamassam berbentuk kurva sinosoida dengan amplitudodan phase gelombang tidak tetap. Hal ini dibabkan karena pengaruh massa benda dan koefisein gaya gesek.
\end{abstract}

Kata Kunci: Sistem massa pegas, Persamaan diferensial orde dua.

\section{PENDAHULUAN}

Pemodelan matematika dimaksudkan untuk mempelajari penomena-penomena dalam kehidupan sehari-hari. Agar masalah yang ada bisa diselesaikan dengan baik dan benar serta sesuai dengan yang diharapkan. Terdapat 3 langkah yang dilakukan dalam menyelesaiakan masalah yaitu [1],

1. Merumuskan masalah

2. Menyelesaikan masalah

3. Melakukan unterpretasi

Salah satunya satu masalah yang yang menjadi bahan kajian yang menarik untuk diteliti adalah sistem massa pegas.

Sistem massa pegas pertama kali diperkenalkan oleh Issac Newton dengan teorinya yang dikenal dengan hukum Newton. Hukum Newton terdiri dati tiga bagian yaitu hukum Newton I, Hukum newton I yang menyatakan bahwa "benda akan tetap diam selama tidak ada gaya yang bekerja padanya". Sedangkan hukum newton II bermakna " gaya yang bekerja pada suatu benda berbanding lurus dengan percepatan dan massa benda tersebut". Hal ini dapat dipahami bahwa semakin berat massa suatu benda maka semakin besar gaya yang dibutuhkan untuk memindahkan benda tersebut, sebaliknya, semakin ringan massa suatu benda maka semakin kecil gaya yang dibutuhkan untuk memindahkan benda tersebut. Adapun hukum newton III berkaitan dengan gaya aksi-rekasi suatu benda.

Selanjutnya, pada paper ini, untuk menyederhanakan penulisan, untuk hukum Newton II akan digunakan istilah "Hukum Newton".

\section{TINJAUAN PUSTAKA}

Pemodelan matematika merupakan suatu bidang kajian matematika yang digunakan untuk menyelesaikan permasalahan dunia real dengan cara membuat beberapa asumsi sehingga dapat dibuat menjadi persamaan matematika. Persamaan matematika tersebut, selanjutnya ditentukan solusinya dengan menggunakan metode matematika baik secara numerik ataupun analitik, sehingga hasilnya diharapkan dapat digunakan untuk menginterpretasi masalah dunia real sebelumnya. Secara umum proses pemodelan dilakukan dengan beberapa tahapan yaitu sebagai berikut;
a) Membuat asumsi
b) Menyatakan variabel dan parameter
c) Membuat model matematika
d) Menyelesaikan model matematika
e) Melakukan interpretasi

Beberapa jenisi model matematika diantaranya;

a) Model diskrit dan kontinu

b) Model Empiris dan Mekanistik

c) Model Statisi dan dinamis

d) Model Deterministik dan stokastik

e) Model Deskriptif

f) Model Eksplanatory

\section{Hukum Newton}

Hukum Newton diperkenalkan oleh salah seorang ilmuan inggris Sir Isaac Newton (1643- 
1727 M). Kepopulerannya di dunia lewat hukum Newton dan gaya gravitasi yang dikemukakannya. Hukum Newton berbunyi

"The acceleration of an object as produced by a net force is directly proportional to the magnitude of the net force, in the same direction as the net force, and inversely proportional to the mass of the object. [1]

Percepatan suatu benda akan berbanding lurus dengan besarnya gaya total (resultan gaya) yang bekerja pada benda tersebut dan berbanding terbalik dengan massanya. Secara matematika dituliskan sebagai

$$
F=m a,
$$

dimana $F$ zadalah gaya (force), $m$ massa $(k g)$ $a$ adalah percepatan $(N)$. Diketahui bahwa kecepata suatu benda diperoleh dengan menggunakan persamaan,

dan percepatannya,

$$
v=\frac{d x}{d t}
$$

$$
a=\frac{d v}{d t}=\frac{d^{2} x}{d t^{2}} .
$$

Sehingga berdasarkan hukum newton pada persamaan (1), diperoleh

$$
F=m \frac{d^{2} x}{d t^{2}}
$$

\section{Hukum Hooke}

Penjelasan tentang hukum Hooke berdasarkan informasi berikut;

"law of elasticity discovered by the English scientist Robert Hooke in 1660, which states that, for relatively small deformations of an object, the displacement or size of the deformation is directly proportional to the deforming force or load. Under these conditions the object returns to its original shape and size upon removal of the load. Elastic behaviour of solids according to Hooke's law can be explained by the fact that small displacements of their constituent molecules, atoms, or ions from normal positions is also proportional to the force that causes the displacement" [2]
Berdasarkan penjelasan tersebut, dapat dipahami bahwa gaya yang bekerja pada suatu pegas dipengaruhi oleh elastisitas pegas. Semakin besar elastisitas pegas maka gaya pegas yang diperlukan untuk memnggerakkan massa akan semakin besar. Adapun secara matematika hukum Hooke dinyatakan sebagai [3]

$$
F=-k x \text {, }
$$

Dimana, $k$ konstanta elastisitas pegas, $x$ posisi pegas.

\section{Sistem Massa Pegas Horisontal Tanpa Gaya gesek}

Asumsi yang dibuat untuk membuat model SMPH yaitu permukaan lantai sangat licin sehingga gaya gesek diabaikan. Dengan menggunakan persamaan 4 dan 5, diperoleh

$$
m \frac{d^{2} x}{d t^{2}}=-k x \text {. }
$$

Atau

$$
m \frac{d^{2} x}{d t^{2}}+k x=0 .
$$

Persamaan (7) merupakan persamaan differensial linear homogen orde dua koefisien konstant.

Solusi persamaan ini adalah ditentukan dengan memisalkan, $x=e^{r t}$ sehingga

$\frac{d x}{d t}=r e^{r t} \quad$ dan $\quad \frac{d^{2} x}{d t^{2}}=r^{2} e^{r t} . \quad$ Selanjutnya, mensubtitusikan ke persamaan (7) diperoleh,

$$
m r^{2} e^{r t}+k e^{r t}=0
$$

Dengan menggunakan operasi aljabar dan fakta bahwa $e^{r t} \neq 0$, maka

Atau

$$
m r^{2}=-k
$$

$$
r= \pm \sqrt{-\frac{k}{m}}= \pm i \frac{k}{m}= \pm i \omega
$$

Jadi, Solusi persamaan (7)

$$
x(t)=c_{1} e^{i \omega t}+c_{2} e^{-i \omega t}
$$

Dengan menggunakan rumus Euler,

$$
\begin{gathered}
e^{i \omega t}=\cos \omega t+i \sin \omega t \\
e^{-i \omega t}=\cos \omega t-i \sin \omega t
\end{gathered}
$$

Sehingga, 


$$
\begin{aligned}
x(t)= & c_{1}(\cos \omega t+i \sin \omega t) \\
& +c_{2}(\cos \omega t-i \sin \omega t) .
\end{aligned}
$$

Dengan menggunakan operasi aljabar.

$$
\begin{aligned}
x(t)= & \left(c_{1}+c_{2}\right) \cos \omega t \\
& +i\left(c_{1}-c_{2}\right) \sin \omega t .
\end{aligned}
$$

Misalkan $a=c_{1}+c_{2}, b=i\left(c_{1}+c_{2}\right)$, dengan mensubstitusikan ke persamaan 12 ,

$$
x(t)=a \cos \omega t+b \sin \omega t .
$$

Persamaan (13) equivalen dengan

$$
x(t)=A \sin (\omega t+\phi) .
$$

Secara, detail dapat dilihat pada [1].

\section{Sistem Massa Pegas Horisontal dengan Gaya Gesek}

Gaya gesek suatu benda dipengaruhi oleh kondisi permukaan benda kerja terhadap permukaan benda lain, seperti kekasaran permukaan dan pelumasan. Gaya gesek dibagi menjadi dua jenis yaitu gaya gesek statis dan gaya gesek dinamis [4] [5].

Selanjutnya, pada diasumsikan bahwa gaya gesek pada sistem massa pegas adalah linear dan dipengaruhi oleh kecepatan. Secara matematik, gaya gesek dituliska dalam bentuk,

$$
F_{g}=-c \frac{d x}{d t}
$$

dimana $c$ adalah koefisien gaya gesek $(c>0)$. Gaya ini disebut sebagai gaya teredam linear (linear damping force) [1].

Dengan menggunakan persamaan (4), (5) dan (14), diperoleh persamaan,

$$
\begin{gathered}
m \frac{d^{2} x}{d t^{2}}=-k x-c \frac{d x}{d t} \\
m \frac{d^{2} x}{d t^{2}}+c \frac{d x}{d t}+k x=0 .
\end{gathered}
$$

Persamaan (15) disebut dengan model sistem massa pegas teredam linear (spring-mass system with a linear damping)

\section{METODOLOGI}

Langkah-langkah yang dilakukan untuk membuat model sistem massa pegas yaitu;

1) Membuat asumsi pada sistem massa pegas
2) Menentukan variabel dan parameter sistem massa pegas

3) Model sistem massa pegas

4) Menentukan titik kesetimbangan sistem massa pegas

5) Membuat analysis terhadap titik kesetimbangan

6) Membuat interpretasi solusi model sistem massa pegas.

\section{PEMBAHASAN}

\section{Sistem Massa Pegas Horisontal}

\section{Asumsi-asumsi}

Dibuat asumsi pada sistem pegas yaitu

1) Benda bergerak satu arah $(\operatorname{arah} x)$

2) Terdapat gaya gesek $F_{g}$

3) Massa benda tidak konstant

\section{Variabel dan parameter}

Variable dan parameter yang digunakan yaitu;

1) Massa benda $m(t)(\mathrm{kg})$,

2) Posisi benda $x(m)$

3) elastisitas pegas $\mathrm{k}\left(\mathrm{kg} / \mathrm{t}^{2}\right)$

4) koefisein gaya gesek c $(N)$

5) Waktu t (s)

\section{Model Sistem Massa Pegas horizontal dengan}

Berdsarkan asumsi yang dibuat di atas maka, langkah pertama dilakukan adalah merumuskan massa benda bergantung pada waktu. Ada dua kemungkinan kondisi berat massa benda yaitu, bertambah atau berkurang. Untuk massa benda yang berkurang terhadap waktu dapat diliha pada artikel [6] yaitu

$$
m(t)=m_{0}-\gamma t
$$

Dimana $\gamma$ adalah debit massa, $m_{0}$ massa awal. Selanjutnya untuk benda yang massanya bertambah, dirumuskan sebagai

$$
m(t)=m_{0}+\gamma t
$$

Dengan menggunakan persamaan

disubstitusikan ke persamaan (15) sehingga,

$$
\left(m_{0}+\gamma t\right) \frac{d^{2} x}{d t^{2}}+c \frac{d x}{d t}+k x=0
$$


Persamaan (18) merupakan persamaan diferensial linear homogen orde dua koefisein tidak konstant. Titik kesetimbangan (equilibrium) persamaan (18) ditentukan dengan menggunakan kondisi $\frac{d x}{d t}=0 \quad$ (tidak ada perpindahan posisi), $\frac{d^{2} x}{d t}=0$ (tidak ada laju percepatan). Sehingga diperoleh

Maka

$$
k x=0 \text {, }
$$

$$
x=0 .
$$

Jadi titik kesetimbangan persamaan (18) adalah $x(t)=0$.

Selanjutnya, menentukan solusi umum persamaan (18) dengan cara sebagai berikut; Misalkan,

$$
\begin{aligned}
x & =e^{r t} \\
\frac{d x}{d t} & =r e^{r t} \\
\frac{d^{2} x}{d t^{2}} & =r^{2} e^{r t}
\end{aligned}
$$

Dengan mensubstitusikan ke persamaan (18)

$$
\begin{aligned}
\left(m_{0}+\gamma t\right) r^{2} e^{r t}+c r e^{r t}+k e^{r t} & =0 \\
\left(\left(m_{0}+\gamma t\right) r^{2}+c r+k\right) e^{r t} & =0
\end{aligned}
$$

Karena $e^{r t} \neq 0$, maka

$\left(\left(m_{0}+\gamma t\right) r^{2}+c r+k\right)=0$

Dengan menggunakan metode pemfaktoran

$$
r_{1,2}=\frac{\left(-c \pm \sqrt{c^{2}-4\left(m_{0}+\gamma t\right) k}\right)}{2\left(m_{0}-\gamma t\right)} .
$$

Jadi solusi umum persamaan (18) adalah,

$$
\begin{gathered}
x(t)=c_{1} e^{\frac{\left(-c+\sqrt{c^{2}-4\left(m_{0}+\gamma t\right) k}\right)}{2\left(m_{0}+\gamma t\right)} t}+ \\
c_{2} e^{\frac{\left(-c-\sqrt{c^{2}-4\left(m_{0}+\gamma t\right) k}\right)}{2\left(m_{0}+\gamma t\right)} t .}
\end{gathered}
$$

Dimana $c_{1}$ dan $c_{2}$ adalah konstanta integrasi.

Selanjutnya, dengan menggunakan software Maple untuk menentukan secara numerik persamaan (18).

Solusi numerik persamaan (18) adalah
Plot solusi persaman (18) dengan menggunakan Maple $\left(k=1, c=1, \gamma=1, m_{0}=1\right)$.

Tabel 1. Solusi Persamaan (18)

\begin{tabular}{|c|c|}
\hline$t$ & $x(t)$ \\
\hline 1 & 3.08195 \\
\hline 2 & 3.72215 \\
\hline 3 & 3.12436 \\
\hline 4 & 1.96565 \\
\hline 5 & 0.65757 \\
\hline 6 & -0.55407 \\
\hline 7 & -1.53393 \\
\hline 8 & -2.22126 \\
\hline 9 & -2.56458 \\
\hline 10 & -2.23011 \\
\hline 11 & -2.56458 \\
\hline 12 & -2.23011 \\
\hline 13 & -1.75575 \\
\hline 14 & -1.19324 \\
\hline 15 & -0.59002 \\
\hline 16 & 0.01260 \\
\hline 17 & 0.58037 \\
\hline 18 & 1.08647 \\
\hline 19 & 1.51132 \\
\hline$:$ & $:$ \\
\hline$:$ & $:$ \\
\hline$:$ & $:$ \\
\hline 48 & -0.92417 \\
\hline 49 & -0.68157 \\
\hline 50 & -0.43029 \\
\hline & \\
\hline 19
\end{tabular}

Selanjutnya, dibuat grafik untuk mengetahui pergerakan pegas pada sistem massa pegas persamaan (18) 


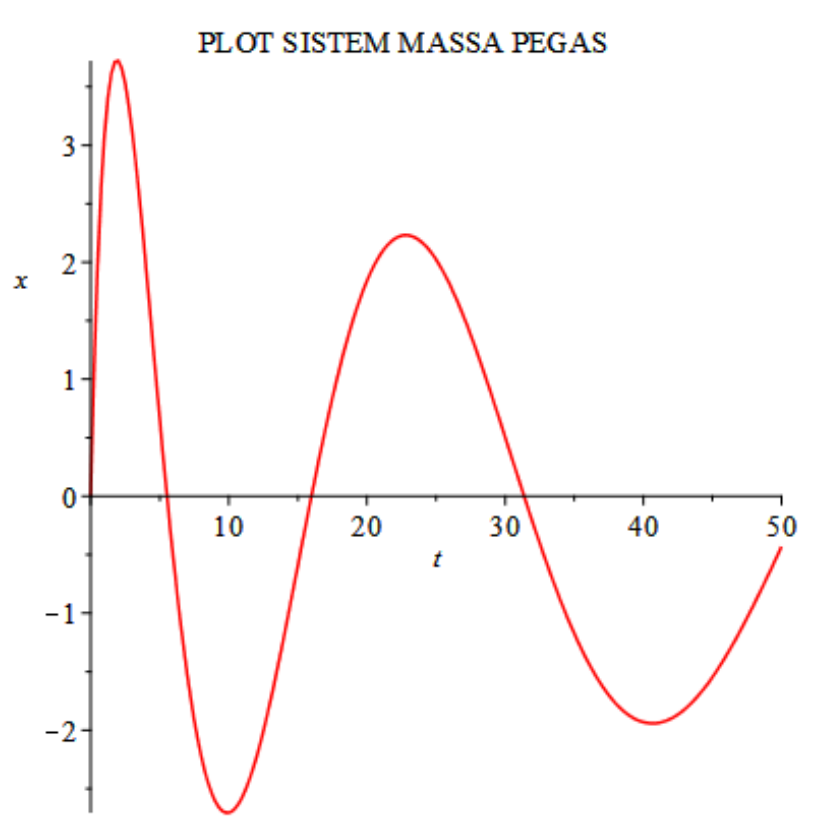

Gambar 1. Solusi persamaan (18)

Pergerakan pegas pada gambar 1. Dapat dipahami, dalam bentuk kurva sinusoida, dimana terdapat perubahan terhadap amplitude (amplitude tidak constant) demikian halnya dengan phase gelombang.

\section{KESIMPULAN}

Berdasarkan hasil yang diperoleh, maka model untuk sistem massa pegas teredam linear dengan massa tidak konstan adalah

$$
\left(m_{0}+\gamma t\right) \frac{d^{2} x}{d t^{2}}+c \frac{d x}{d t}+k x=0 .
$$

Titik kesetimbangan berada pada $x(t)=0$. Pergerakan massa berbentuk kurva sinusoida dengan amplitude berubah-ubah.
[4] e. a. M. Bahar Fitrianto, "Pengujian Koefisien Gesek Permukaan Plat Baja St 37 Pada Bidang," Momentum, vol. 11 No.1, no. April, pp. 13-18, 2015.

[5] H. a. P. H. Winingsih, "Eksperimen Gaya Gesek untuk Menguji Nilai Koefisien Gesekan," Jurnal Science Tech, vol. 3 No.2, no. Agustus, pp. 121-126, 2017.

\section{DAFTAR PUSTAKA}

[1] R. Haberman, Matematical Model Mechanical Vibration, Populations Dynamic, and Traffic Flow, United State Of America: Prentice-Hall, 1998.

[2] The Physics Clasroom, "Newton Second Law," 2 Februari 2019. [Online].

Available: https://www.physicsclassroom.com/class/newtlaws/Lesson3/Newton-s-Second-Law.

[3] A. Augustyn, "Enciclopaedia Britannica," 2522019. [Online].

Available:

https://www.britannica.com/science/Hookes-law. 